\title{
PENERAPAN TEKNIK SHADOWING DENGAN MEDIA AUDIO-VISUAL DALAM PEMBELAJARAN BERBICARA BAHASA PERANCIS
}

\author{
Wulan Dwi Andani, Soeprapto Rakhmat, \& Yadi Mulyadi \\ Universitas Pendidikan Indonesia \\ Email: wulandwi.andani@gmail.com; soeprapto.rakhmat@upi.edu; yadimulyadi@upi.edu
}

How to cite (in APA Style): Andani, W.D., Rakhmat, S., \& Mulyadi, Y. (2018). Penerapan teknik shadowing dengan media audio-visual dalam pembelajaran berbicara bahasa Perancis. Barista: Jurnal Kajian Bahasa dan Pariwisata, 5(2), Desember 2018, 180-190.

Abstrak: Penelitian ini dilatarbelakangi oleh penelitian yang dilakukan oleh Wardhana (2018) dan Puspita (2016). Dalam penelitian ini, teknik shadowing dengan media audiovisual digunakan dengan tujuan untuk mengukur dan mendeskripsikan hasil pembelajaran berbicara sebelum dan sesudah diterapkannya teknik tersebut, serta untuk memperoleh data perihal tanggapan siswa terhadap teknik tersebut dalam pembelajaran berbicara bahasa Perancis. Desain penelitian yang digunakan yaitu pre-experimental design dengan pola one group pre-test - post-test. Hasil penelitian yang diperoleh menunjukkan adanya peningkatan yang signifikan dari hasil prates dan pascates kemampuan berbicara bahasa Perancis. Hal ini dibuktikan dengan hasil perhitungan data statistik mengenai nilai uji t dengan hasil analisis data yang didapatkan dari nilai rata-rata prates adalah 68,9 dan nilai rata-rata pascates mencapai 85,6. Dengan demikian, kemampuan berbicara siswa meningkat $16,8 \%$ setelah diterapkannya teknik shadowing. Dari hasil tersebut didapatkan nilai $t_{\text {hitung }} 12,49$ dengan $\mathrm{db}=30$. Maka dapat diperoleh kesimpulan bahwa $t_{\text {tabel }}$ sebesar $2,04<t_{\text {hitung }}$ sebesar 12,49 untuk taraf signifikansi 5\% dan nilai $t_{\text {tabel }}$ sebesar 2,75 $<\mathrm{t}_{\text {hitung }}$ sebesar 12,49 untuk taraf signifikansi $1 \%$. Hal ini membuktikan bahwa nilai $t_{\text {hitung }}>t_{\text {tabel }}$ yang artinya hipotesis kerja $\left(\mathrm{H}_{\mathrm{k}}\right)$ diterima. Hal tersebut berarti penggunaan teknik shadowing dapat meningkatkan pembelajaran berbicara bahasa Perancis.

Kata kunci: Teknik shadowing; keterampilan berbicara; media audio-visual

\section{APPLICATION OF SHADOWING TECHNIQUE WITH AUDIO-VISUAL MEDIA IN LEARNING SPEAKING FRENCH LANGUAGE}

\begin{abstract}
This research was motivated by research conducted by Wardhana (2018) and Puspita (2016). In this research, shadowing technique with audio-visual media were used with the aim of measuring and describing the results of speaking learning before and after the implementation of these techniques, and to obtain data about students' responses to these techniques in learning to speak French. The research design used was pre-experimental design with one group pre-test - post-test pattern. The results obtained showed a significant increase in the results of pre-test and post-test French language skills. This is evidenced by the results of statistical data calculations regarding the value of $t$ test with the results of data analysis obtained from the average value of pre-test is 68.9 and the average post-test score reached 85.6. Thus, students' speaking ability increased by $16.8 \%$ after the application of shadowing techniques. From these results we got the tcount of 12.49 with $\mathrm{db}=30$. Then it can be concluded that the ttable of $2.04<$ tcount of 12.49 for the significance level of $5 \%$ and the value of $t$ table of $2.75<$ tcount of 12.49 for the significance level of $1 \%$. This proves that $t$ count $>t$ table which means the work hypothesis (Hk) is accepted. This means that the use of shadowing techniques can improve learning to speak French
\end{abstract}

Keywords: Shadowing technique; speaking skill; audio-viusal media. 


\section{PENDAHULUAN}

Keterampilan berbicara merupakan salah satu keterampilan berbahasa yang sangat penting dikuasai pembelajar bahasa asing khususnya bahasa Perancis.. Hal ini sejalan dengan yang dipaparkan oleh Leong dan Ahmadi (2017) bahwa "berbicara adalah salah satu keterampilan yang paling penting untuk dikembangkan dan ditingkatkan sebagai sarana komunikasi yang efektif. Salah satu tujuan bahasa asing adalah untuk meningkatkan keterampilan komunikasi sebagai luaran dari hasil pembelajaran, (Aleksandrzak, 2011; Bashir, Azeem \& Dogar, 2011; Hasan, 2014, Malihah, 2010; Oradee, 2012).

Namun ditemukan beberapa kesulitan yang dihadapi siswa saat proses pembelajaran berbicara bahasa Perancis. Hal tersebut dibuktikan dengan sulitnya pembelajar mengekspresikan diri dalam berbicara menggunakan bahasa asing secara efektif karena tidak menemukan kata dan ekspresi yang tepat (Leong \& Ahmadi, 2017). Sementara itu Kosdian (2016) menyebutkan bahwa siswa memiliki masalah dalam kelancaran (adanya keraguan saat pelafalan), masalah dalam pengucapan (kesalahan fonem dalam artikulasi vokal, konsonan dan intonasi), kesalahan tata bahasa, serta keterbatasan pengetahuan kosakata. Sebagai upaya untuk menghadapi kesulitan tersebut, diperlukannya teknik pembelajaran yang tepat dan diharapkan dapat meningkatkan kemampuan berbicara bahasa Perancis siswa SMK. Salah satunya teknik pembelajaran shadowing.

Menurut Hamada (2012: 2), shadowing didefinisikan sebagai kegiatan menggunakan headphone untuk mendengar dan mengucapkan kembali suatu suara seperti yang dilakukan oleh burung beo. Efektivitas shadowing sebagai sebuah metode pembelajaran menyimak pernah diteliti pada tahun 2012 oleh Yo Hamada, seorang profesor di Universitas Akita di Jepang. Saat itu, Hamada mengaplikasikan shadowing pada pembelajaran Bahasa Inggris dan mendapatkan hasil bahwa shadowing mampu meningkatkan kemampuan menyimak (listening) pembelajarnya. Teknik shadowing telah menjadi topik yang menarik di bidang pengajaran dan pembelajaran bahasa asing, Sumarsih (2017). Selanjutnya hasil penelitian Puspita (2016) menyimpulkan bahwa kemampuan mahasiswa mengalami perubahan setelah diterapkannya teknik shadowing dalam pembelajaran kaiwa. Kemampuan berbicara partisipan dalam aspek kelancaran berbicara, pelafalan dan intonasi mengalami peningkatan berkat diterapkannya teknik shadowing. Kemudian hasil penelitian Wardhani (2018) yang menyimpulkan bahwa teknik shadowing dapat membantu mahasiswa dalam pembelajaran berbicara bahasa Inggris. Selain itu, peningkatan kemampuan berbicara bahasa Inggris mahasiswa setelah adanya teknik ini sebesar $84,6 \%$. Artinya teknik shadowing sangat efektif digunakan dalam pembelajaran berbicara.Dengan teknik yang sama, peneliti terdorong untuk meneliti pengaplikasian shadowing dalam pembelajaran bahasa Perancis untuk mengetahui kemampuan berbicara (la production orale). Karena teknik shadowing belum pernah menyentuh pembelajaran berbicara bahasa Perancis. Selain teknik pembelajaran yang sesuai, harus didukung dengan penggunaan media pembelajaran yang menarik. Hal ini bertujuan untuk menciptakan suasana pembelajaran yang menarik dan dapat dipahami oleh siswa atau pembelajar dengan mudah. Dalam penelitian ini, peneliti memilih penggunaan media audio-visual. Hal ini sejalan dengan yang dikatakan Raharjo (1991) dalam Rusman, Kurniawan, dan Riyana (2012, p. 65) bahwa dalam proses pembelajaran hanya dapat mengingat $20 \%$ dari apa yang kita dengar, namun dapat mengingat $50 \%$ dari apa yang dilihat dan didengar. Selain itu, media pembelajaran memiliki manfaat yaitu: 1) pembelajaran akan lebih menarik perhatian siswa sehingga dapat menumbuhkan motivasi belajar, 2) metode pembelajaran akan 
lebih bervariasi, tidak semata-mata komunikasi verbal melalui penuturan oleh guru sehingga siswa tidak merasa bosan dengan pembelajaran; 3) bahan pembelajaran akan lebih jelas maknanya sehingga lebih dipahami oleh siswa dan dapat menguasai tujuan pembelajaran secara lebih baik; 4) siswa lebih banyak melakukan kegiatan belajar dan aktivitas lain seperti mengamati, melakukan, dan mendemonstrasikan.

Berdasarkan penjelasan di atas, peneliti tertarik untuk melakukan penelitian berjudul "Penerapan Teknik Shadowing dengan Media Audio-visual dalam Pembelajaran Berbiacara Bahasa Perancis". Dengan demikian, penelitian ini berupaya untuk: (1) mengukur dan mendeskripsikan hasil kemampuan berbicara bahasa Perancis siswa SMA sebelum dan setelah penerapan teknik shadowing dan; (2) memperoleh informasi mengenai pendapat siswa terhadap teknik shadowing dalam pembelajaran berbicara bahasa Perancis.

\section{METODE}

Walliman (2011, p.7) mengemukakan bahwa "metode penelitian adalah teknik yang digunakan dalam melakukan penelitian. Peneliti menggunakan suatu alat untuk mengumpulkan data, mengurutkan, dan menganalisis informasi sehingga mendapat beberapa kesimpulan". Dalam penelitian ini, metode yang digunakan adalah desain praeksperimental yang mengukur penggunaan teknik shadowing untuk meningkatkan kemampuan berbicara bahasa Perancis siswa SMK kelas X UPW 1 SMKN 1 Bandung Tahun Ajaran 2018/2019.

Desain yang digunakan oleh peneliti dalam penelitian ini adalah desain OneGroup Pretest-Posttest, yang terdiri dari tiga langkah: prates pada langkah pertama untuk mengukur kemampuan berbicara bahasa Perancis responden sebelum menerapkan teknik shadowing, setelahnya dilakukan perlakuan menggunakan teknik shadowing dalam proses pembelajaran. Langkah terakhir adalah pascates untuk mengukur kemampuan berbicara bahasa Perancis setelah menerapkan teknik shadowing. Sampel penelitian ini yaitu 31 siswa kelas X UPW 1 SMKN 1 Bandung Tahun Ajaran 2018/2019. Selanjutnya, peneliti menggunakan beberapa teknik pengumpulan data, yaitu: (1) studi kepustakaan; (2) tes; (3) observasi; dan (4) kuesioner.

\section{HASIL DAN PEMBAHASAN}

\section{1) Prates}

Pada penelitian ini, terdapat tiga tahapan yaitu: prates, perlakuan dan pascates. Tahap pertama yang peneliti lakukan adalah melakukan prates pada tanggal 23 Mei 2019. Pada tahap ini, peneliti memberikan tes berbicara berupa tes monolog dengan tema memperkenalkan diri. Hal ini dilakukan untuk mengukur kemampuan berbicara bahasa Perancis sebelum diterapkannya teknik shadowing. Perolehan skor berdasarkan kriteria penilaian yang memiliki 5 aspek yaitu compréhension : Les informations de la consigne (informasi dan pemahaman terhadap perintah), performance Globale: Fludité, attitude, vitesse (Penampilan secara keseluruhan: kelancaran, sikap dan kecepatan), correction phonétique: prononciation (pelafalan), lexique approprié: vocabulaire (kosakata), structures simples correctes: Grammaire (kesesuaian tata bahasa). Skor tertinggi dari setiap aspek adalah 5 dan skor terendah adalah 1.

Berikut ini adalah hasil nilai prates dari 31 siswa yang dituangkan ke dalam bentuk tabel. 
Tabel 1 Hasil Nilai Prates Berdasarkan Aspek Penilaian

\begin{tabular}{|c|c|c|c|c|c|c|c|}
\hline \multirow{3}{*}{$\begin{array}{c}\text { Nomor } \\
\text { Responden }\end{array}$} & \multicolumn{5}{|c|}{ Kriteria Penilaian } & \multirow{2}{*}{ Skor } & \multirow{2}{*}{ Nilai } \\
\hline & C & PG & CP & LA & SSC & & \\
\hline & $1-5$ & $1-5$ & $1-5$ & $1-5$ & $1-5$ & Max. 25 & Max. 100 \\
\hline 1 & 3 & 2 & 2 & 3 & 3 & 13 & 52 \\
\hline 2 & 3 & 3 & 3 & 4 & 4 & 17 & 68 \\
\hline 3 & 4 & 4 & 3 & 4 & 4 & 19 & 76 \\
\hline 4 & 4 & 3 & 2 & 4 & 4 & 17 & 68 \\
\hline 5 & 4 & 4 & 3 & 4 & 4 & 19 & 76 \\
\hline 6 & 4 & 4 & 4 & 4 & 3 & 19 & 76 \\
\hline 7 & 4 & 3 & 3 & 3 & 3 & 16 & 64 \\
\hline 8 & 4 & 4 & 3 & 4 & 4 & 19 & 76 \\
\hline 9 & 4 & 4 & 3 & 4 & 4 & 19 & 76 \\
\hline 10 & 4 & 4 & 3 & 4 & 4 & 19 & 76 \\
\hline 11 & 4 & 4 & 3 & 3 & 4 & 18 & 72 \\
\hline 12 & 3 & 3 & 3 & 4 & 4 & 17 & 68 \\
\hline 13 & 4 & 4 & 3 & 4 & 4 & 19 & 76 \\
\hline 14 & 4 & 3 & 3 & 4 & 4 & 18 & 72 \\
\hline 15 & 4 & 3 & 3 & 3 & 3 & 16 & 64 \\
\hline 16 & 4 & 3 & 3 & 4 & 4 & 18 & 72 \\
\hline 17 & 4 & 3 & 3 & 3 & 3 & 16 & 64 \\
\hline 18 & 4 & 3 & 3 & 3 & 4 & 17 & 68 \\
\hline 19 & 4 & 4 & 3 & 4 & 4 & 19 & 76 \\
\hline 20 & 4 & 3 & 3 & 3 & 3 & 16 & 64 \\
\hline 21 & 3 & 3 & 3 & 3 & 3 & 15 & 60 \\
\hline 22 & 3 & 3 & 3 & 3 & 3 & 15 & 60 \\
\hline 23 & 3 & 2 & 2 & 3 & 2 & 12 & 48 \\
\hline 24 & 3 & 2 & 2 & 2 & 3 & 12 & 48 \\
\hline 25 & 4 & 3 & 4 & 4 & 4 & 19 & 76 \\
\hline 26 & 3 & 3 & 2 & 2 & 3 & 13 & 52 \\
\hline 27 & 4 & 3 & 3 & 4 & 3 & 17 & 68 \\
\hline 28 & 4 & 3 & 3 & 4 & 4 & 18 & 72 \\
\hline 29 & 5 & 4 & 4 & 4 & 4 & 21 & 84 \\
\hline 30 & 5 & 4 & 4 & 4 & 3 & 20 & 80 \\
\hline 31 & 5 & 4 & 4 & 4 & 4 & 21 & 84 \\
\hline Jumlah & 119 & 102 & 93 & 110 & 110 & 534 & 2136 \\
\hline
\end{tabular}

\section{Keterangan:}

$\mathbf{C}=$ Compréhension : Les informations de la consigne (informasi dan pemahaman terhadap perintah)

PG = Performance Globale: Fludité, attitude, vitesse (Penampilan secara keseluruhan: kelancaran, sikap dan kecepatan)

$\mathbf{C P}=$ Correction phonétique: prononciation (pelafalan)

LA = Lexique approprié: vocabulaire (kosakata)

SSC $=$ Structures simples correctes: Grammaire (kesesuaian tata bahasa).

Pengelompokan kategori nilai siswa yang diperoleh pada saat penelitian dapat diketahui melalui format yang digunakan peneliti menurut Nurgiyantoro (2010, p.253) sebagai berikut. 
Tabel 2 Format Penilaian

\begin{tabular}{cc}
\hline $\begin{array}{c}\text { Nilai ubahan skala } \\
\text { sepuluh }\end{array}$ & Keterangan \\
\hline $100-85$ & Sangat baik \\
$84-75$ & Baik \\
$74-60$ & Cukup \\
$59-40$ & Kurang \\
$39-0$ & Sangat kurang \\
\hline
\end{tabular}

Berdasarkan tabel di atas, peneliti dapat mengetahui bahwa terdapat 2 responden mencapai nilai tertinggi 84 dan 2 responden dengan nilai terendah 48 . Maka dapat dikatakan bahwa terdapat 12 siswa dengan kategori nilai baik, 15 siswa dengan kategori cukup, dan 4 siswa dengan kategori kurang.

\section{2) Perlakuan Pembelajaran}

Kemudian pada tanggal 27 Mei 2019, peneliti melaksanakan perlakuan pembelajaran menggunakan teknik shadowing dengan media audio-visual selama 90 menit. Dalam penelitian ini, peneliti memilih jenis selective shadowing. Berikut ini merupakan tahapan-tahapan yang dilakukan selama perlakuan dengan menerapkan teknik shadowing. Dalam pelaksanaan perlakuan, peneliti memberikan materi secara singkat tentang présenter quelqu'un (memperkenalkan seseorang) dengan media audio-visual. Media audio-visual tersebut berisi pembicaraan monolog oleh penutur asli bahasa Perancis dengan materi memperkenalkan seseorang (tokoh idola). Hal ini bertujuan untuk memberikan stimulus pelafalan bahasa Perancis siswa terkait ungkapan yang berhubungan dengan materi yang diberikan peneliti.

I. Kegiatan Inti

1. Peneliti memberikan materi secara singkat mengenai présenter quelqu'un (memperkenalkan seseorang) dengan menggunakan media tayangan power point yang berisi ungkapan-ungkapan umum dalam memperkenalkan seseorang dalam bahasa Perancis, informasi-informasi apa saja yang harus ada pada saat memperkenalkan seseorang dalam bahasa Perancis, kosakata yang berkaitan dengan memperkenalkan seseorang, serta kata kerja yang digunakan seperti être, avoir, s'appeler, habiter, faire, dan aimer.

Sebelum melanjutkan pada langkah berikutnya, peneliti membagikan video terlebih dahulu sehingga video tersebut dapat dimiliki oleh setiap responden secara mandiri. Hal tersebut dilakukan agar tujuan pembelajaran dapat tercapai.

2. Peneliti menjelaskan teknik shadowing dalam pembelajaran berbicara bahasa Perancis. Selanjutnya, peneliti memaparkan langkah-langkah berbicara dengan menggunakan teknik shadowing sekaligus memberikan contoh dalam pelaksanaannya agar memudahkan siswa untuk mempraktekkan teknik tersebut.

Sebelum langkahlangkah dimulai, peneliti menyajikan sebuah media audio-visual mengenai memperkenalkan seseorang. Terdapat 5 langkah dalam menggunakan teknik shadowing diantaranya: a) slash reading (membaca serta memahami dan 
memeriksa kata yang

kurang dipahami); b) Full shadowing (berlatih menirukan secara berulang hingga hasil yang didapatkan sekitar 70 sampai $80 \%$ mirip); c) Repeating and shadowing (mengulang dengan membaca teks lalu menirukan); d) Translation (menerjemahkan sebagian demi sebagian, e) Repeating (reproduction) yaitu mengulang dengan cara pause by pause.

3. Peneliti menggunakan media audio-visual yaitu video memperkenalkan seseorang yang bersumber dari youtube yang disampaikan oleh penutur asli bahasa Perancis. Video lainnya juga disampaikan guna memberikan stimulus pelafalan siswa terkait dengan materi yang dijelaskan sebelumnya, seperti video pelafalan nomor dan video mengenai profesi. Berikut merupakan transkrip video memperkenalkan

seseorang:

"Je vous présente ma célébrité préférée. Il s'appelle Zinèdine Zidane. Il est né le 23 juin milles neuf cents soixante-douze. il est né à Marseille en France. Il a 43ans. il est français et algérien. Il est footballeur professionnel à la retrait et il est manequin chez mango. Il est marié, sa femme s'appelle Veronic. Il a 4 enfants, 4 fils, Kenzo, Lucas, Theo et Eriaz. Il a 4 frères et une sœur. Il habite à Madrid en Espagne ».

4. Peneliti membagikan transkrip di atas kepada siswa, hal ini untuk memudahkan siswa dalam membaca dan memahami pembelajaran. Meskipun dalam video tersebut sudah tersedia subtitel, peneliti tetap memberikan kertas transkrip.

5. Peneliti melatih pelafalan menggunakan teknik shadowing dengan media audio-visual. Hal ini dilakukan secara bersamasama oleh seluruh siswa. Peneliti menginstruksi langkah-langkah teknik shadowing seperti yang telah dijelaskan sebelumnya yaitu:

a) slash reading, guru dansiswa membaca serta memahami dan memeriksa kata yang kurang dipahami;

b) full shadowing, guru dan siswa berlatih menirukan secara berulang hingga hasil yang didapatkan sekitar 70 sampai 80 $\%$ mirip;

c) repeating and shadowing, guru dan siswa mengulang dengan membaca teks lalu menirukan;

d) translation, guru dan siswa menerjemahkan sebagian demi sebagian,

e) repeating (reproduction) yaitu guru dan siswa mengulang dengan cara pause by pause.

6. Peneliti menginstruksikan siswa agar berlatih secara mandiri dengan teman sebangkunya untuk terus melakukan pengulangan pelafalan menggunakan teknik shadoiwng. Kemudian peneliti memastikan siswa 
mengikuti kegiatan

berbicara dengan cara

berkeliling kelas.

7. Peneliti memberikan soal perintah (la consigne) sebagai tes akhir atau pascates dengan tema memperkenalkan seseorang. Terdapat 2 pilihan yaitu memperkenalkan keluarga atau memperkenalkan idola favorit. Siswa diberikan kebebasan untuk menentukan pilihan tersebut. Informasi yang harus dijelaskan yaitu: le nom et le prénom (nama lengkap), la profession (profesi), la nationalité (kewarganegaraan), l'âge (usia), l'adresse (alamat), dan l'activité le week-end (kegiatan akhir pekan/waktu luang).

8. Siswa mempersiapkan informasi yang harus tersampaikan, kemudian diberi kesempatan untuk berlatih pelafalan dan hal lain dengan teknik shadowing. Peneliti memastikan kembali siswa dengan berkeliling kelas. Hal ini dilakukan dengan tujuan memfasilitasi agar siswa dapat bertanya jika dirasa ada yang kurang dipahami.

II. Tahap Penutup

1. Peneliti memberikan kesempatan untuk siswa bertanya dan berdiskusi mengenai kesulitan selama pembelajaran

2. Peneliti memberikan refleksi kepada siswa dengan adanya kesimpulan.

3. Pembelajaran ditutup, peneliti meminta siswa mempersiapkan diri untuk melaksanakan pascates.

Dalam tahap perlakuan, peneliti berperan sebagai guru. Kegiatan peneliti diobservasi oleh observer pada lembar yang berisi aspek-aspek kriteria penilaian peneliti sebagai guru, begitu pula dengan kegiatan siswa yang diobservasi oleh observer dengan aspek-aspek penilaian siswa. Terdapat 5 aspek yang menjadi kriteria penilaian guru yaitu: 1) kemampuan peneliti dalam membuka pelajaran; 2) penguasaan materi pelajaran; 3) penerapan strategi pembelajaran; 4) penggunaan media dalam pembelajaran;5) kegiatan akhir pembelajaran. Berdasarkan hasil akhir yang diperoleh menunjukkan bahwa peneliti mendapatkan nilai sangat baik dengan perolehan skor 4,8 dari skor maksimal 5. Adapun lembar observasi siswa yang terdiri dari 6 aspek. Berdasarkan hasil penilaian dari observer, bahwa siswa dapat dikatakan aktif selama proses pembelajaran.

\section{3) Pascates}

Tahap selanjutnya adalah tahap pascates keterampilan berbicara responden dengan tes monolog mengenai tema memperkenalkan seseorang. Pelaksanaan pascates yaitu pada tanggal 27 Mei 2019 setelah dilaksanakannya perlakuan. Kemudian, peneliti menganalisis hasil prates dan pascates. Berikut adalah nilai 31 siswa dan koefisien antara nilai prates dan pascates. 
Andani, Rakhmat, \& Mulyadi: Penerapan teknik shadowing dengan memmdia audio-visual...

Tabel 3 Jumlah Kuadrat Deviasi Responden

\begin{tabular}{|c|c|c|c|c|c|}
\hline $\begin{array}{c}\text { Nomor } \\
\text { Responden }\end{array}$ & Prates (x) & Posttest (y) & Selisih $(d=y-x)$ & $\begin{array}{c}\text { Deviasi } \\
(x d)\end{array}$ & $x d^{2}$ \\
\hline 1 & 52 & 72 & 20 & 3,23 & 10,41 \\
\hline 2 & 68 & 84 & 16 & $-0,77$ & 0,60 \\
\hline 3 & 76 & 88 & 12 & $-4,77$ & 22,79 \\
\hline 4 & 68 & 76 & 8 & $-8,77$ & 76,99 \\
\hline 5 & 76 & 80 & 4 & $-12,77$ & 163,18 \\
\hline 6 & 76 & 92 & 16 & $-0,77$ & 0,60 \\
\hline 7 & 64 & 80 & 16 & $-0,77$ & 0,60 \\
\hline 8 & 76 & 96 & 20 & 3,23 & 10,41 \\
\hline 9 & 76 & 80 & 4 & $-12,77$ & 163,18 \\
\hline 10 & 76 & 88 & 12 & $-4,77$ & 22,79 \\
\hline 11 & 72 & 84 & 12 & $-4,77$ & 22,79 \\
\hline 12 & 68 & 92 & 24 & 7,23 & 52,21 \\
\hline 13 & 76 & 80 & 4 & $-12,77$ & 163,18 \\
\hline 14 & 72 & 84 & 12 & $-4,77$ & 22,79 \\
\hline 15 & 64 & 84 & 20 & 3,23 & 10,41 \\
\hline 16 & 72 & 84 & 12 & $-4,77$ & 22,79 \\
\hline 17 & 64 & 84 & 20 & 3,23 & 10,41 \\
\hline 18 & 68 & 80 & 12 & $-4,77$ & 22,79 \\
\hline 19 & 76 & 100 & 24 & 7,23 & 52,21 \\
\hline 20 & 64 & 84 & 20 & 3,23 & 10,41 \\
\hline 21 & 60 & 88 & 28 & 11,23 & 126,02 \\
\hline 22 & 60 & 76 & 16 & $-0,77$ & 0,60 \\
\hline 23 & 48 & 68 & 20 & 3,23 & 10,41 \\
\hline 24 & 48 & 76 & 28 & 11,23 & 126,02 \\
\hline 25 & 76 & 96 & 20 & 3,23 & 10,41 \\
\hline 26 & 52 & 92 & 40 & 23,23 & 539,44 \\
\hline 27 & 68 & 84 & 16 & $-0,77$ & 0,60 \\
\hline 28 & 72 & 88 & 16 & $-0,77$ & 0,60 \\
\hline 29 & 84 & 100 & 16 & $-0,77$ & 0,60 \\
\hline 30 & 80 & 96 & 16 & $-0,77$ & 0,60 \\
\hline 31 & 84 & 100 & 16 & $-0,77$ & 0,60 \\
\hline Jumlah & 2136 & 2656 & 520 & & $\Sigma \mathrm{X}_{\mathrm{d}}{ }^{2}=1.677,42$ \\
\hline Rata-rata & 68,9 & 85,6 & 16,7 & & \\
\hline
\end{tabular}

Ada pun hasil perolehan nilai dari prates dan pascates jika dikelompokkan berdasarkan format penilaian Nurgiyantoro (2010, p.253) yaitu :

1) Hasil prates menunjukkan bahwa 12 responden dengan kategori nilai baik, 15 responden dengan kategori nilai cukup baik dan 4 dengan kategori nilai kurang.

2) Hasil pascates menunjukkan bahwa 13 responden dengan kategori nilai sangat baik, 16 siswa dengan kategori nilai baik dan 2 
siswa dengan kategori nilai cukup baik.

Berikut adalah pemaparan dari kriteria penilaian keterampilan berbicara:

\section{a. Informasi Informasi dan pemahaman terhadap perintah}

Informasi yang harus dijelaskan tersebut yaitu: le nom et le prénom (nama lengkap), la profession (profesi), la nationalité (kewarganegaraan), l'âge (usia), l'adresse (alamat), dan l'activité le week-end (kegiatan akhir pekan/waktu luang).

Dari data di atas, terdapat terdapat $35 \%$ responden mendapatkan skor maksimal yaitu skor 5 yang artinya mengerti soal secara keseluruhan tanpa ada kesulitan. Selanjutnya, 58\% responden yang memperoleh skor 4 , artinya mengerti soal hampir seluruhnya meskipun terkadang harus ada pengulangan. Terdapat sebagian kecil yaitu 7\% meraih skor 3 yang artinya memahami sebagian besar soal, namun memerlukan penjelasan secara perlahan dan sering terjadi pengulangan.

\section{b. Kelancaran, sikap dan kecepatan}

Aspek selanjutnya adalah penampilan secara keseluruhan (kelancaran, sikap dan kecepatan). Dari 31 responden, terdapat $39 \%$ yang mendapatkan skor tertinggi yaitu 5. Hal tersebut berarti pembicaraan responden sangat lancar dan terstruktur seperti layaknya penutur asli. Kemudian 45\% responden meraih skor 4, artinya pembicaraan lancar namun sesekali kurang lancar dan berbicara sedikit karena dipengaruhi oleh kesulitankesulitan bahasa. Sebagian kecil responden dengan persentase 16\% memperoleh skor 3 yang artinya pembicaraan kurang lancar, masih adanya keraguan, dan kalimat tidak lengkap dipengaruhi oleh kesulitan-kesulitan Bahasa.

\section{c. Pelafalan}

Berikutnya pada aspek ketiga mengenai pelafalan. Terdapat $16 \%$ responden mencapai skor tertinggi yaitu 5, artinya ucapan sudah standar. Kemudian terdapat $68 \%$ yang mendapat skor 4 , hal ini berarti ucapan jelas, tetapi memiliki aksen tertentu dan tidak mengganggu pembicaraan. Terdapat $16 \%$ lainnya mendapat skor 3 yang artinya terdapat pengaruh ucapan asing atau dialek daerah tetapi kesalahan ucapan tidak menyebabkan kesalahpahaman.

\section{d. Kosakata}

Pada aspek ini, responden mampu menggunakan kosakata yang sesuai dengan tema yang diberikan. Dari 31 siswa, terdapat $68 \%$ responden yang mencapai skor tertinggi yaitu 5. Hal tersebut berarti pemilihan dan penggunaan kosakata sudah tepat. Kemudian terdapat 32\% responden yang mendapatkan skor 4 yang artinya penggunaan kosakata atau istilah terbatas, tetapi tidak membatasi pembicaraan. Dengan demikian, dapat dikatakan bahwa seluruh responden sudah memahami kosakata sesuai penggunaannya.

\section{e. Tata Bahasa}

Pada aspek ini, responden mampu menggunakan kosakata yang sesuai dengan tema yang diberikan. Dari 31 siswa, terdapat $68 \%$ responden yang mencapai skor tertinggi yaitu 5. Hal tersebut berarti pemilihan dan penggunaan kosakata sudah tepat. Kemudian terdapat 32\% responden yang mendapatkan skor 4 yang artinya penggunaan kosakata atau istilah terbatas, tetapi tidak membatasi pembicaraan. Dengan demikian, dapat dikatakan bahwa seluruh responden sudah memahami kosakata sesuai penggunaannya.

Berdasarkan data prates dan pascates di atas, peneliti dapat mengetahui perbandingan nilai prates dan pascates dari masing-masing responden seperti yang ditunjukkan pada grafik. 


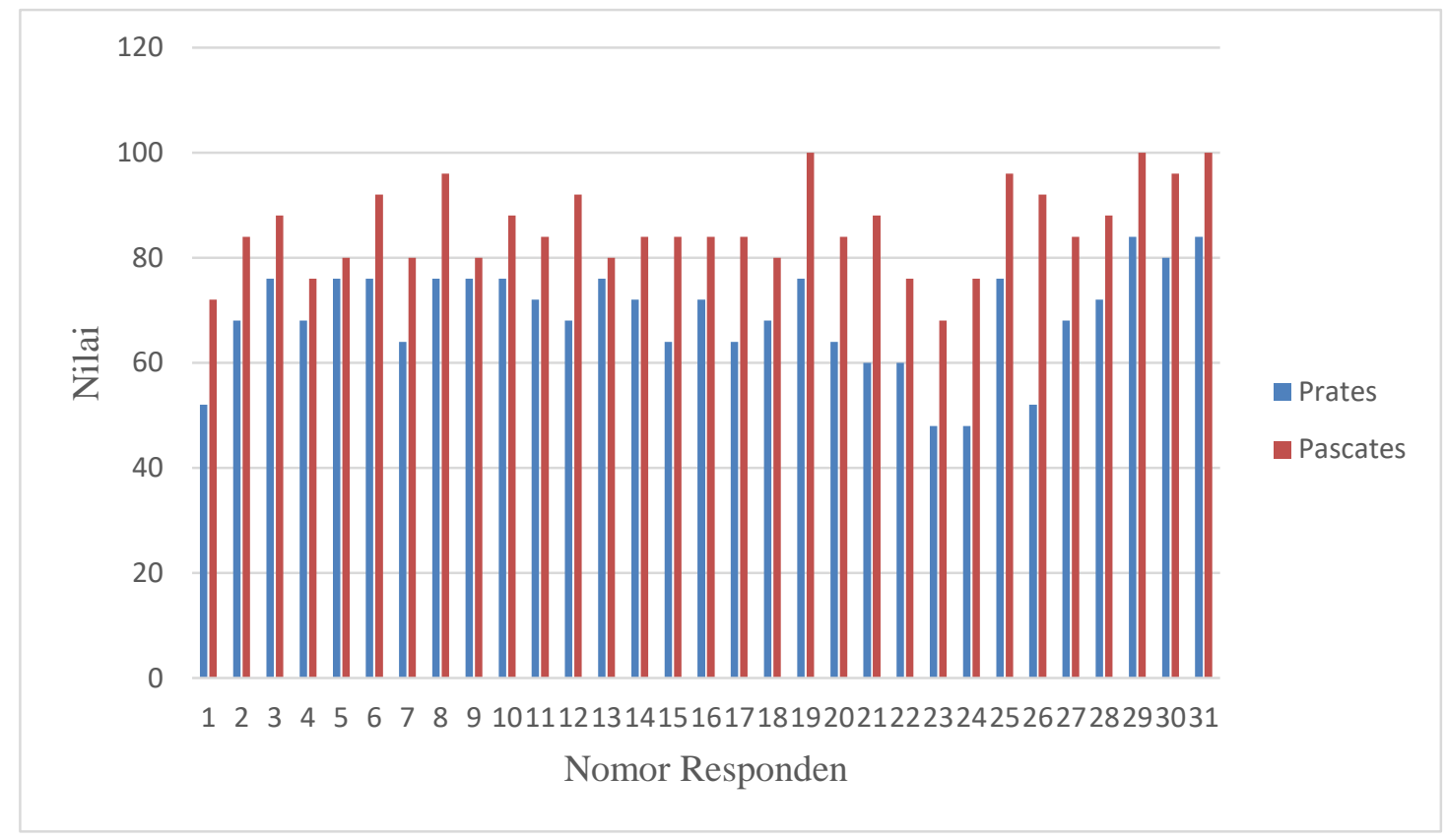

Grafik 1 Perbandingan Nilai Prates dan Pascates

Grafik di atas menunjukkan bahwa seluruh nilai siswa meningkat, hal ini berarti nilai pascates lebih besar dari nilai prates. Berdasarkan hasil data yang diperoleh, peneliti dapat mengetahui bahwa persentase rata-rata kemampuan berbicara bahasa Perancis 31 siswa sebelum diterapkannya teknik shadowing pada prates adalah 2.136 dengan perhitungan $2.136 / 31 \times 100 \%=68,9 \%$. Adapun pada tahap pascates yaitu setelah diterapkannya teknik shadowing, jumlah nilai pascates kemampuan berbicara bahasa Perancis 31 siswa sebesar 2.656. Jumlah nilai tersebut diratakan ke dalam bentuk persentase dengan rumus $2.656 / 31 \times 100 \%=85,6 \%$. Hasil tersebut menunjukkan bahwa siswa kelas X UPW 1 SMKN 1 Bandung mengalami peningkatan sebesar $16,7 \%$ pada saat pascates.

Sebuah teknik pembelajaran tentu memiliki kelebihan dan kekurangan, menurut tanggapan responden mengenai kelebihan teknik shadowing yang didapat dari hasil angket yaitu dapat meningkatkan kepercayaan diri saat berbicara bahasa Perancis, membantu memahami struktur kalimat bahasa Perancis, dapat diaplikasikan dalam pembelajaran secara mandiri di rumah serta meningkatkan pengetahuan kosakata. sedangkan kekurangan teknik shadowing yaitu membutuhkan proses yang lama pada saat pembelajaran, terdapat beberapa tahapan pembelajaran dalam teknik shadowing dan sulit diaplikasikan saat belajar sendiri di rumah.

\section{SIMPULAN}

Berdasarkan hasil pelaksanaan penelitian, dapat diketahui bahwa hasil kemampuan berbicara siswa SMKN 1 Bandung tahun ajaran 2018/2019 memiliki rata-rata 69, artinya nilai tersebut berada pada rentang cukup. Hal tersebut disebabkan oleh kesulitan yang dialami siswa pada saat pembelajaran berbicara bahasa Perancis diantaranya: sulitnya pelafalan dalam bahasa Perancis, sulitnya memahami struktur kalimat bahasa Perancis dan keterbatasan kosakata yang dimiliki serta kurangnya rasa percaya diri (gugup).

Setelah diterapkannya teknik shadowing dalam pembelajaran berbicara bahasa Perancis, kemampuan berbicara seluruh responden mengalami peningkatan. Pada data yang diperoleh serta hasil pengolahan dan analisis data penelitian ini, dapat ditarik kesimpulan 
bahwa kemampuan berbicara siswa mengalami kenaikan sebesar 16,8\%. Data tersebut diperoleh dari perbandingan hasil prates yang mendapatkan mean sebesar 68,9\% dan mean pascates sebesar $85,6 \%$.

Teknik shadowing efektif bila digunakan pada pembelajaran berbicara bahasa Perancis. Hal ini dapat dilihat dari hasil pengujian hipotesis kerja dan hipotesis nol, Dalam penelitian ini, hipotesis kerja dapat diterima serta adanya perbedaan dari responden yang cukup signifikan pada kemampuan berbicara bahasa Perancis sebelum dan sesudah diterapkannya teknik shadowing tersebut. Adapun tanggapan responden berdasarkan hasil angket yang diperoleh mengemukakan bahwa teknik shadowing dapat memotivasi siswa dalam pembelajaran berbicara bahasa Perancis.

\section{DAFTAR PUSTAKA}

Aleksandrzak, M. (2011). Problems and challenges in teaching and learning speaking at advanced level. Uniwersytet Im. Adama Mickiewicza W Poznaniu.

Bashir, M., Azeem, M., \& Dogar, A. H. (2011). Factor effecting students' English speaking skills. British Journal of Arts and Social Sciences, 2(1).

Hamada, Y. (2016). Shadowing: Who benefits and how? Uncovering a booming EFL teaching technique for listening comprehension. Sage Journal : Language Teaching Research, 20(1) 36. doi: http://journals.sagepub.com/doi/pdf/ 10.1177/1362168815597504

Hasan, A. A. A. (2014). The effect of using task-based learning in teaching English on the oral performance of the secondary school students. International Interdisciplinary Journal of Education, 3(2), 250-264.
Kosdian, Odi. (2016). Improving Students' Speaking Skill by Using Picture Strip Story. Indonesian EFL Journal. 2(2), 100-109.

https://journal.uniku.ac.id/index.ph $\mathrm{p} / \mathrm{IEFLJ} /$ article/view/642

Leong, L-M., \& Ahmadi, M.S. (2017). An Analysis of Factors Influencing Learners' English Speaking Skill. International Journal of Research in English Education, Vol. 2 (1) 34-41. http://ijreeonline.com/article-1-38en.pdf

Malihah, N. (2010). The effectiveness of speaking instruction through taskBased language teaching. Register, 3(1), 85-101.

Oradee, T. (2012). Developing speaking skills using three communicative activities (discussion, problemsolving, and role-playing). International Journal of Social Science and Humanity, 2(6): 533-535.

Puspita, A.L, et al. (n.d). Teknik Shadowing dalam Pembelajaran Kaiwa. Japanedu. 1(3), 44-49. doi: http://ejournal.upi.edu/index.php/ja panedu/article/view/5940

Wardhana, P.N. (2018). Teknik Shadowing Meningkatkan Kemampuan Mahasiswa Berbicara Bahasa Inggris. SPHOTA: Jurnal Linguistik dan Sastra. 10(1), 1-7. doi: http://sphota.stibasaraswati.ac.id/ind ex.php/sphota/article/view/91/56

\section{UCAPAN TERIMA KASIH}

Peneliti mengucapkan terima kasih kepada semua pihak yang telah membantu dalam pelaksanaan penelitian ini di antaranya kepada Patria Hertana, S.Pd., sebagai guru mata pelajaran bahasa Perancis di SMKN 1 Bandung, dan para siswa kelas X UPW 1 SMKN 1 Bandung sebagai partisipan dalam penelitian ini. 